\title{
Metabolic alterations in broiler chickens experimentally infected with sporulated oocysts of Eimeria maxima
}

\author{
Alteraçóes metabólicas em frangos de corte infectados experimentalmente com \\ oocistos esporulados de Eimeria maxima
}

Fagner Luiz da Costa Freitas ${ }^{1 *}$

${ }^{1}$ Veterinary Parasitology Laboratory, Federal University of the Southern Frontier - UFFS, Realeza, PR, Brazil

Received March 15, 2014

Accepted June 02, 2014

\begin{abstract}
Metabolic and morphometric alterations of the duodenal villi caused by parasitism of chickens by Eimeria maxima were evaluated, using 100 male Cobb birds, randomly distributed into two groups (control and infected). The infected group was inoculated with $0.5 \mathrm{ml}$ of a solution containing $5 \times 10^{3}$ sporulated oocysts of Eimeria maxima. Ten birds per sample were sacrificed on the $6^{\text {th }}, 11^{\text {th }}, 22^{\text {nd }}$ and $41^{\text {st }}$ days post-infection (dpi). In order to evaluate the alterations, samples of duodenum, jejunum and ileum fragments were collected after necropsy for histological analysis. Villus biometry was determined by means of a slide graduated in microns that was attached to a binocular microscope. To evaluate the biochemical data, $5 \mathrm{ml}$ of blood were sampled from the birds before sacrifice. The statistical analyses were performed using the GraphPad 5 statistical software for Windows. Tukey's multiple comparison test $(p<0.05)$ was performed for the different dpi's and the unpaired $\mathrm{t}$ test for the difference between the groups. Infection by E. maxima causes both qualitative and quantitative alterations to the structure of the intestinal villi, thereby interfering with the absorption of nutrients such as calcium, phosphorus, magnesium, protein and lipids, with consequent reductions in the birds' weights.
\end{abstract}

Keywords: Eimeria maxima, metabolism, experimental infection.

\section{Resumo}

Foram avaliadas alteraçôes metabólicas e morfométricas das vilosidades intestinais causadas pelo parasitismo de frangos por Eimeria maxima, sendo utilizadas 100 aves da linhagem Coob, machos, distribuídos aleatoriamente em dois grupos experimentais: grupo controle, inoculado com $0,5 \mathrm{ml}$ de água destilada; grupo infectado, inoculado com $0,5 \mathrm{ml}$ de solução contendo $5 \times 10^{3}$ oocistos esporulados de Eimeria maxima. Foram sacrificadas 10 aves por coleta no 0, 6, 11, 22 e 41 dias pós-infecção. Para avaliar as alteraçóes foram retiradas, após necropsia, amostras de fragmentos do duodeno, jejuno e íleo para análise histológica. A determinação da biometria de vilosidades foi realizada por meio de lâmina milimetrada acoplada a um microscópio binocular. Para avaliação dos dados bioquímicos foram coletados $5 \mathrm{ml}$ de sangue das aves antes da eutanásia. As análises estatísticas foram realizadas, utilizando-se o programa estatístico Graphpad Prism. 5 - Windows e realizado o teste de comparaçóes múltiplas de Tukey $(\mathrm{p}<0,05)$ para os diferentes dpi's e o Teste T não Pareado para diferença entre os grupos. A infecção por E. maxima provoca alteraçôes qualitativas e quantitativas das vilosidades intestinais, interferindo na absorção de nutrientes, como cálcio, fósforo, magnésio, proteínas e lipídios, com consequente redução no peso das aves.

Palavras-chave: Eimeria maxima, metabolismo, infecção experimental.

\section{Introduction}

Coccidiosis is a parasitic infection caused by species of intracellular protozoa belonging to the genus Eimeria spp.. The three species that most commonly affect the poultry industry are: $E$. tenella, E. maxima and E. acervulina (CARDOZO; YAMAMURA, 2006;

\footnotetext{
*Address for correspondence: Fagner Luiz da Costa Freitas

Laboratório de Parasitologia Veterinária, Universidade Federal da Fronteira Sul - UFFS, Avenida Rubem Cesar Caselani, 38, CEP 85770-000, Realeza, PR, Brasil

e-mail: fagner.freitas@uffs.edu.br
}

McDOUGALD, 2007). Among these, E. maxima is considered to be the one with the highest pathogenicity (SHARMAN et al., 2010), causing lesions that may compromise the absorption surface of birds' digestive tract (JANG et al., 2010; JENKINS et al., 2009). In addition, it may also favor establishment of other diseases, since the damaged intestinal tissues and the functional changes to the intestinal tract that it causes may break down the natural defense barriers and allow colonization by various pathogenic agents. 
The main function of the small intestine is nutrient absorption and, for nutrients to be satisfactorily absorbed by the organism, the structure and functional capacity of the intestine need to be intact. It is known that the intestinal mucosa develops through two primary associated cytological events: cell renewal (proliferation and differentiation), resulting from the mitotic divisions undergone by totipotent cells located in the crypt and along the villi; and loss of cells due to desquamation, which occurs naturally at the apex of the villi. The balance between these two processes is determined by a constant renewal rate and, thus, the digestive and intestinal absorption capacities (PELICANO et al., 2003).

E. maxima has affinity for lateral and apical areas of the villi, causing destruction of the villi with consequent decreased capacity for intestinal digestion and absorption of nutrients such as zinc, oleic acid, methionine, histidine, calcium, glucose and xanthophyll (LILLEHOJ; OKAMURA, 2003), thus altering the biochemical and hematological parameters.

Glucose metabolism regulation in birds is similar to that of mammals, but with quantitative differences. According to Freeman (1970), anorexia and intestinal tract inflammation caused by conditions such as coccidiosis inhibit glucose absorption. Thus, birds enter a state of hypoglycemia, induce the pancreas to produce glucagon and use the hepatic glycogen reserves, presenting hypoglycemia only in severe cases due to inhibition of hepatic glycogenolysis.

Considering the importance of intestinal villus integrity for nutrient absorption and weight performance among poultry, the objective of the present study was to evaluate the morphometric alterations of the intestinal villi and nutrient concentrations in birds that were subjected to infection with $5 \times 10^{3}$ sporulated oocysts of E. maxima.

\section{Materials and Methods}

A total of 100 male seven-day-old Cobb broiler chickens were used. They were randomized according to weight and distributed into two experimental groups: a control group, consisting of $50 \mathrm{birds}$ that were inoculated with $0.5 \mathrm{ml}$ of distilled water; and an infected group, consisting of 50 birds that were inoculated with $0.5 \mathrm{ml}$ of solution with $5 \times 10^{3}$ sporulated oocysts of Eimeria maxima, obtained from a pool of samples from chicken farms in Brazil and multiplied in birds free of specific pathogen agents. The purity of strain (in vivo) was performed using morphological and biological characteristics, as described by Costa and Paiva (2009). For the inoculation, all birds in the experiment were manually restrained and were inoculated orally, with the aid of an automatic pipette.

Each group was placed in an iron cage with dimensions of $1 \mathrm{~m}$ in length $\times 2 \mathrm{~m}$ in width $\times 1.5 \mathrm{~m}$ in height. Clean water and balanced feed without anticoccidials were provided in troughs and these were washed with water and neutral detergent and flame-sterilized every 12 hours, to avoid the risk of reinfection among the birds. The cage used in the experiment was suspended, avoiding contact with animal's excreta. The composition of the feed used (based on corn and soy bran) was in accordance with the nutritional rules and standards established by the National
Research Council (NRC, 1998). It was isonutrient and isoenergetic, and was provided to the birds "ad libitum".

The biological material was sampled on the $6^{\text {th }}, 11^{\text {th }}, 22^{\text {nd }}$ and $41^{\text {st }}$ days post-infection (dpi) to enable laboratory tests. The birds were sacrificed by means of cervical dislocation (ten birds per group per date), in accordance with legal slaughter methods and as prescribed by a resolution from the Animal Wellbeing and Ethics Committee.

For the histopathological evaluation, fragments of the duodenum, jejunum and ileum were removed on the $6^{\text {th }}, 11^{\text {th }}$ and $22^{\text {nd }} \mathrm{dpi}$. The samples measured $1 \mathrm{~cm}$ when closed, and were opened longitudinally. They were washed in a phosphate buffer solution (0.1 M, pH 7.4) and fixed in $10 \%$ formol solution for 36 hours. They were then dehydrated in an ascending series of alcohols to remove the fixer and, later on, were clarified in xylol and embedded in paraffin. Semi-serial histological sections of thickness $7 \mu \mathrm{m}$ were cut using a microtome, and seven histological sections were placed on each slide. These were stained using hematoxylin and eosin, and were observed under an optical microscope. The microscopic images were recorded by means of a Dino Eye Capture 2.0 digital eyepiece, version 1.2.7, coupled to a Bioval binocular microscope, and were stored on a computer.

A morphometric study on the height of the villi and the perimeter and depth of the intestinal crypts was performed using an eyepiece graduated in micrometers attached to a binocular microscope with an objective lens of 10x. Only the villi that presented a visible set and defined epithelium were measured. Five villi per histological section in five different sections were selected, with a minimum distance of $100 \mu \mathrm{m}$ between them. In total, 25 villi per bird were sampled in order to measure the crypt height, width and depth. The width of the villi was measured considering the mean of three points on the same villus as used in height measurements, in the apical, medial and basal areas.

Throughout the experimental period, clinical and parasitological examinations were carried out daily on the birds. For the parasitological analyses on feces, sampling was done daily, from the $1^{\text {st }} \mathrm{dpi}$ onwards, and a pool was collected from each tray in a zigzag manner for each group. First, the control group was sampled and then the infected group. After sampling, the material was forwarded to the Laboratory of Animal Parasitic Diseases located in the Department of Preventive Medicine of São Paulo State University (UNESP), Jaboticabal campus, São Paulo.

The oocysts were counted using a McMaster chamber. To detect the pre-patency and patency periods of E. maxima, the centrifugal flotation technique in a supersaturated solution of sodium chloride $(\mathrm{NaCl})$ was used to isolate the oocysts.

The blood was sampled via an intra-cardiac route, using $5 \mathrm{ml}$ syringes and disposable needles. From this volume, $1 \mathrm{ml}$ was deposited in a sterile test tube containing sodium fluorite ethylenediaminetetraacetic acid (fluorite-EDTA) and $3 \mathrm{ml}$ in a sterile test tube without anticoagulant in order to obtain plasma and serum, respectively, after centrifugation. Immediately after sampling, the vials with blood and sodium fluorite were forwarded to the laboratory for plasma glucose assaying by means of the enzymatic method using a commercial kit (Labtest ${ }^{\circledR}$ Diagnóstica, Belo Horizonte, $\mathrm{MG}$ ), with readings in a spectrophotometer device (LabQuest ${ }^{\circledR}$ Diagnóstica, Belo Horizonte, MG). 
Serum lipid and mineral levels were measured in the Clinical Pathology Laboratory of the Federal University of Tocantins. The measurements included triacylglycerols of the lipoproteins, total cholesterol, high density lipoprotein cholesterol (HDL-c), low density lipoprotein cholesterol (LDL-c) and very low density lipoprotein cholesterol (VLDL-c). Protein metabolism was evaluated through the concentrations of total proteins, albumin and globulin. All of these biochemical parameters were determined using commercial kits (Diagnóstica Pró Vida ${ }^{\circledR}$, São José do Rio Preto, SP). The reference values that were used in the present study were based on the minimum and maximum values found in the birds on day zero of the experimental period.

To determine the live weight, the chickens were weighed on a precision scale after six hours without feed. The objective of this technique was to reduce the amount of food present in the gut tract, allowing a better handling of the viscera during necropsy. They were then sacrificed by means of decapitation between the occipital and atlas bones using a previously sterilized knife. The blood was allowed to drain out for two minutes using a cone adapted for chicken slaughtering. The skin and feathers were then removed manually. The chickens were eviscerated by means of an abdominal incision using scissors and, finally, were weighed in order to obtain the carcass weight. To calculate the carcass yield, the weight of the eviscerated carcass was considered (without viscera, feet, head and abdominal fat) in relation to the live weight multiplied by 100 .

The data obtained from biometry on the intestinal villi and from biochemical tests and weight gain analysis were subjected to analysis of variance, using Tukey's multiple comparisons test $(p<0.05)$, in order to evaluate the different post-infection days; and the unpaired t test $(\mathrm{p}<0.05)$ was used to evaluate comparisons among the different groups through the Prisma 5 software.

\section{Results}

In the present study, the pre-patent period lasted for five days, and the patent period lasted for twelve days, for Eimeria maxima. In the infected group, the histopathological examination showed a growing inflammatory process in the intestinal villi, characterized by diffuse lymphocytic infiltrate in the lateral and apical regions of the villi and associated with villi atrophy and presence of several parasite forms of E. maxima, being more aggressive on the jejunum and ileum making it impossible to biometric evaluation of these regions. Table 1 presents the biometric parameters relating to the duodenum of the birds in the control and infected groups. The parasitic infection resulted in reduction of villus height, but there was only a significant difference on the $11^{\text {th }} \mathrm{dpi}(\mathrm{p}<0.05)$. The villus width and crypt depth on the $6^{\text {th }} \mathrm{dpi}$ were compromised probably due to edema in the area. From analyzing the infected group separately, a significant difference in crypt depth $(\mathrm{p}<0.0045)$ was evident between the $6^{\text {th }}$ and $22^{\text {nd }} \mathrm{dpi}$, which may also have been associated with edema.

Table 2 presents the nutrient concentrations of the plasma and serum of the birds belonging to the experimental groups. No significant difference was observed between the control and infected groups for the serum concentrations of glucose. The serum concentrations of total proteins presented a significant decrease only on the $6^{\text {th }} \mathrm{dpi}$, while the serum albumin of the infected animals remained within the normal range from the beginning to the end of the experimental period. The results showed that there were reductions in calcium and phosphorus absorption at the post-patente stage of the disease, observed on the $22^{\text {nd }} \mathrm{dpi}$ for calcium and on the $22^{\text {nd }}$ and $41^{\text {st }} \mathrm{dpi}$ for phosphorus. However, regarding the serum values of magnesium, the results showed that there was a significant reduction $(\mathrm{p}<0.0001)$ of this mineral in the acute phase of the disease, observed on the $6^{\text {th }}$ dpi. No significant differences in the serum values of total cholesterol, HDL and LDL were observed. However, a reduction in their means was observed on the $6^{\text {th }} \mathrm{dpi}$, followed by a reduction in the serum values of triacylglycerol and VLDL ( $p<0.0001)$, which showed that there was lower absorption of the lipid series in the initial phase of the disease.

The results found for weight gain showed significant differences on all dpi's in relation to $0 \mathrm{dpi}$ for both groups, which was considered normal, since the birds were in the growth stage throughout the experiment. Comparison among the groups showed that the results were significant from the $6^{\text {th }}$ to the $22^{\text {nd }}$ dpi $(p<0.05)$, thus demonstrating that the parasite affected the birds' weight gain throughout their development. However, no statistically significant differences were found between the mean weight gains of the birds infected by E. maxima and the birds of the control group on the $41^{\text {st }} \mathrm{dpi}(\mathrm{p}>0.05)$, although these birds presented the highest weight gain mean throughout the study. The carcass yield followed the birds' development, as expected, since the birds were in a growth phase. Analysis of means showed

Table 1. Biometric characteristics $(\mu \mathrm{m})$ of the duodenum of broiler chickens experimentally infected with $5 \times 10^{3}$ sporulated oocysts of Eimeria maxima.

\begin{tabular}{|c|c|c|c|c|c|}
\hline \multirow{2}{*}{ Parameters } & \multirow{2}{*}{ Experimental groups } & \multicolumn{3}{|c|}{ Days post-infection (dpi) } & \multirow{2}{*}{$P$ ANOVA } \\
\hline & & $6^{\text {th }} \mathrm{dpi}$ & $11^{\text {th }} \mathrm{dpi}$ & $22^{\text {nd }} \mathrm{dpi}$ & \\
\hline \multirow[t]{2}{*}{ Height } & Control & $1451.51 \pm 539.91 \mathrm{~ns}$ & $1710.5 \pm 211.16 \mathrm{a}$ & $1576.74 \pm 454.7^{\mathrm{ns}}$ & 0.7103 \\
\hline & Infected & $1117.30 \pm 470.88^{\mathrm{ns}}$ & $1259 \pm 180.31 \mathrm{~b}$ & $1062.62 \pm 286.64$ ns & 0.7630 \\
\hline \multirow[t]{2}{*}{ Width } & Control & $56.88 \pm 14.55 \mathrm{Ab}$ & $163.59 \pm 25.46 \mathrm{~B}$ & $106.06 \pm 43.88 \mathrm{AB}$ & 0.0067 \\
\hline & Infected & $100.73 \pm 15.12 \mathrm{a}$ & $114.49 \pm 37.48^{\mathrm{ns}}$ & $80.88 \pm 18.89^{\text {ns }}$ & 0.2611 \\
\hline \multirow[t]{2}{*}{ Crypt depth } & Control & $95.99 \pm 13.06 \mathrm{Ab}$ & $121.99 \pm 19.27 \mathrm{~B}^{\mathrm{ns}}$ & $71.99 \pm 8.84 C^{\mathrm{ns}}$ & 0.0008 \\
\hline & Infected & $144.51 \pm 30.43 \mathrm{Aa}$ & $102.66 \pm 24.51 \mathrm{AB}$ & $68.66 \pm 8.25 B^{\mathrm{ns}}$ & 0.0045 \\
\hline
\end{tabular}

${ }_{A, B}$ different capital letters in the same line indicate significant differences $(\mathrm{p}<0.05)$ through Tukey's multiple comparison test. ${ }^{a, b}$ different lower case letters in the same column indicate significant differences $(\mathrm{p}<0.05)$ between the control and the infected groups through the unpaired $\mathrm{t}$ test. ${ }^{\mathrm{n}}$ non-significant through Tukey's test. 
Table 2. Serum levels of glucose, proteins, minerals and lipids according to the day post-infection, among broiler chickens experimentally infected with $5 \times 10^{3}$ sporulated oocysts of Eimeria maxima.

\begin{tabular}{|c|c|c|c|c|c|c|c|}
\hline \multirow{2}{*}{ Parameters } & \multirow{2}{*}{$\begin{array}{l}\text { Experimental } \\
\text { groups }\end{array}$} & \multicolumn{5}{|c|}{ Days post-infection (dpi) } & \multirow{2}{*}{$P$ ANOVA } \\
\hline & & $\mathbf{0}^{\text {th }} \mathrm{dpi}$ & $6^{\text {th }} \mathrm{dpi}$ & $11^{\text {th }} \mathrm{dpi}$ & $22^{\text {nd }} \mathrm{dpi}$ & $41^{\text {nd }}$ dpi & \\
\hline \multirow[t]{2}{*}{ Glucose } & Control & $201.8 \pm 32.0^{\mathrm{ns}}$ & $212.3 \pm 19.4^{\mathrm{ns}}$ & $243.8 \pm 47.4^{\mathrm{ns}}$ & $236.8 \pm 42.6^{\mathrm{ns}}$ & $227.7 \pm 27.45^{\mathrm{ns}}$ & 0.1233 \\
\hline & Infected & $190.9 \pm 23.4^{\mathrm{ns}}$ & $204.9 \pm 13.5^{\mathrm{ns}}$ & $236.1 \pm 79.2^{\mathrm{ns}}$ & $233.9 \pm 36.0^{\mathrm{ns}}$ & $233.4 \pm 27.20^{\mathrm{ns}}$ & 0.1559 \\
\hline \multirow[t]{2}{*}{ Total protein } & Control & $1.88 \pm 0.25^{\mathrm{ns}}$ & $2.67 \pm 0.56 \mathrm{a}$ & $1.73 \pm 0.68^{\mathrm{ns}}$ & $2.79 \pm 0.71^{\mathrm{ns}}$ & $2.42 \pm 0.92^{\mathrm{ns}}$ & 0.1131 \\
\hline & Infected & $2.10 \pm 0.24^{\mathrm{ns}}$ & $1.84 \pm 0.41 \mathrm{~b}$ & $2.04 \pm 0.27^{\mathrm{ns}}$ & $2.49 . \pm 0.89^{\mathrm{ns}}$ & $2.34 \pm 0.63^{\mathrm{ns}}$ & 0.0023 \\
\hline \multirow[t]{2}{*}{ Albumin } & Control & $1.02 \pm 0.15^{\mathrm{ns}}$ & $1.21 \pm 0.16^{\mathrm{ns}}$ & $1.24 \pm 0.37^{\mathrm{ns}}$ & $1.40 \pm 0.27^{\mathrm{ns}}$ & $1.45 \pm 0.6^{\mathrm{ns}}$ & 0.0005 \\
\hline & Infected & $1.04 \pm 0.17^{\mathrm{ns}}$ & $1.21 \pm 0.49^{\mathrm{ns}}$ & $1.34 \pm 0.47^{\mathrm{ns}}$ & $1.56 \pm 0.22^{\mathrm{ns}}$ & $1.6 \pm 0.23^{\mathrm{ns}}$ & 0.0158 \\
\hline \multirow[t]{2}{*}{ Calcium } & Control & $8.47 \pm 2.55^{\mathrm{ns}}$ & $9.56 \pm 3.24^{\mathrm{ns}}$ & $8.30 \pm 2.72^{\mathrm{ns}}$ & $9.83 \pm 2.41^{\mathrm{a}}$ & $9.11 \pm 2.58^{\mathrm{ns}}$ & 0.9345 \\
\hline & Infected & $7.51 \pm 2.94^{\mathrm{ns}}$ & $8.37 \pm 2.01^{\mathrm{ns}}$ & $8.30 \pm 2.36^{\mathrm{ns}}$ & $7.89 \pm 1.85 b$ & $9.39 \pm 1.67^{\mathrm{ns}}$ & 0.6862 \\
\hline \multirow[t]{2}{*}{ Phosphorus } & Control & $7.11 \pm 0.92^{\mathrm{ns}}$ & $9.99 \pm 2.24^{\mathrm{ns}}$ & $8.45 \pm 2.44^{\mathrm{ns}}$ & $6.72 \pm 3.09^{a}$ & $6.58 \pm 3.87 \mathrm{a}$ & 0.0524 \\
\hline & Infected & $7.52 \pm 1.82^{\mathrm{ns}}$ & $8.45 \pm 2.04^{\mathrm{ns}}$ & $7.52 \pm 2.89^{\mathrm{ns}}$ & $3.73 \pm 2.86 b$ & $0.97 \pm 0.67 b$ & 0.0125 \\
\hline \multirow[t]{2}{*}{ Magnesium } & Control & $3.21 \pm 0.68^{\mathrm{ns}}$ & $3.19 \pm 0.89 \mathrm{a}$ & $1.73 \pm 0.74^{\mathrm{ns}}$ & $1.92 \pm 0.43^{\mathrm{ns}}$ & $1.54 \pm 0.52^{\mathrm{ns}}$ & $<0.0001$ \\
\hline & Infected & $3.31 \pm 1.02^{\mathrm{ns}}$ & $2.3 \pm 0.72 b$ & $1.37 \pm 0.27^{\mathrm{ns}}$ & $1.86 \pm 0.59^{\mathrm{ns}}$ & $1.51 \pm 0.51^{\mathrm{ns}}$ & $<0.0001$ \\
\hline \multirow[t]{2}{*}{ Total cholesterol } & Control & $179.81 \pm 49.52^{\text {ns }}$ & $161.12 \pm 49.52^{\mathrm{ns}}$ & $132.52 \pm 22.98^{\mathrm{ns}}$ & $146.03 \pm 31.97^{\mathrm{ns}}$ & $132.34 \pm 40.25^{\mathrm{ns}}$ & 0.1754 \\
\hline & Infected & $171.95 \pm 28.84^{\mathrm{ns}}$ & $112.85 \pm 31.22^{\mathrm{ns}}$ & $128.94 \pm 20.4^{\mathrm{ns}}$ & $164.20 \pm 53.24^{\mathrm{ns}}$ & $159.91 \pm 31.97^{\mathrm{ns}}$ & 0.0052 \\
\hline \multirow[t]{2}{*}{ Triacylglycerol } & Control & $43.46 \pm 12.76^{\mathrm{ns}}$ & $118.05 \pm 65.55 \mathrm{a}$ & $91.54 \pm 39.21^{\mathrm{ns}}$ & $86.86 \pm 32.34^{\mathrm{ns}}$ & $106.50 \pm 48.06^{\mathrm{ns}}$ & 0.0131 \\
\hline & Infected & $47.67 \pm 12.89^{\mathrm{ns}}$ & $28.08 \pm 23.90 \mathrm{~b}$ & $95.02 \pm 17.57^{\mathrm{ns}}$ & $86.30 \pm 27.90^{\mathrm{ns}}$ & $137.61 \pm 49.74^{\mathrm{ns}}$ & 0.0059 \\
\hline \multirow{2}{*}{$\begin{array}{l}\text { High density } \\
\text { lipoprotein }\end{array}$} & Control & $112 \pm 30.38^{\mathrm{ns}}$ & $81.22 \pm 29.19^{\mathrm{ns}}$ & $75.20 \pm 17.61^{\mathrm{ns}}$ & $81.20 \pm 11.86^{\mathrm{ns}}$ & $91 \pm 21.79^{\mathrm{ns}}$ & 0.0879 \\
\hline & Infected & $101 \pm 22.94^{\mathrm{ns}}$ & $81.22 \pm 22.29^{\mathrm{ns}}$ & $80.66 \pm 14.43^{\mathrm{ns}}$ & $88.11 \pm 9.46^{\mathrm{ns}}$ & $89 \pm 17.35^{\mathrm{ns}}$ & 0.1641 \\
\hline \multirow{2}{*}{$\begin{array}{l}\text { Very low density } \\
\text { lipoprotein }\end{array}$} & Control & $8.69 \pm 2.55^{\mathrm{ns}}$ & $23.61 \pm 13.11 \mathrm{a}$ & $18.31 \pm 7.84^{\mathrm{ns}}$ & $17.37 \pm 6.47^{\mathrm{ns}}$ & $21.30 \pm 9.61^{\mathrm{ns}}$ & 0.0368 \\
\hline & Infected & $9.53 \pm 2.58^{\mathrm{ns}}$ & $5.62 \pm 4.78 b$ & $19.00 \pm 3.51^{\mathrm{ns}}$ & $17.26 \pm 5.58^{\mathrm{ns}}$ & $27.52 \pm 9.95^{\mathrm{ns}}$ & $<0.0001$ \\
\hline \multirow{2}{*}{$\begin{array}{l}\text { Low density } \\
\text { lipoprotein }\end{array}$} & Control & $59.12 \pm 60.52^{\mathrm{ns}}$ & $71.88 \pm 74.67^{\mathrm{ns}}$ & $52.37 \pm 48.01^{\mathrm{ns}}$ & $54.32 \pm 54.34^{\mathrm{ns}}$ & $47.06 \pm 50.59^{\mathrm{ns}}$ & 0.7758 \\
\hline & Infected & $73.73 \pm 24.07^{\mathrm{ns}}$ & $41.98 \pm 17.32^{\mathrm{ns}}$ & $37.78 \pm 23.48^{\mathrm{ns}}$ & $91.63 \pm 52.51^{\mathrm{ns}}$ & $75.81 \pm 48.20^{\mathrm{ns}}$ & 0.0808 \\
\hline
\end{tabular}

a,b different lower case letters in the same column indicate significant differences $(\mathrm{p}<0.05)$ between the control and the infected groups through the unpaired $\mathrm{t}$ test.

${ }^{\text {ns }}$ non-significant through the unpaired t test at $5 \%$ significance level.

that the parasite affected the carcass yield over the entire growth period of the birds, although this difference was significant only on the $11^{\text {th }} \mathrm{dpi}(\mathrm{p}<0.05)$.

\section{Discussion}

Although Eimeria maxima specifically acts on the medial segment of the intestine, the present results suggest that migration of the parasite to a higher portion of the intestine may have occurred, since there were lesions typical for this species on the villi in the duodenal area. In addition, its presence was observed through histopathological examination on all the birds. Similar results were observed by Cardozo and Yamamura (2006) and Idris et al. (1997), when studying species of Eimeria spp. in naturally infected birds. They found E. maxima parasitizing the proximal and medium areas of the small intestine.

The species of the genus Eimeria spp. that infect and develop in intestinal cells drastically modify the structure and appearance of the villi. Idris et al. (1997) inoculated a dose of $2.5 \times 10^{3}$ sporulated oocysts of $E$. maxima and observed a reduction in the height of the villi on the $7^{\text {th }} \mathrm{dpi}$.

The edema observed may be due to the inflammatory process and to the dilation of the submucosa and proliferation of epithelium cells in the acute phase of the disease. Similar results were observed by Zulpo et al. (2007) when inoculating $2 \times 10^{4}$ sporulated oocysts of E. maxima, which resulted in edema, as well as dilation of the submucosa and proliferation of the epithelium cells. According to Montagne et al. (2003), an increase in the villus-to-crypt ratio corresponds to an increase in digestion and absorption. However, what is observed is that the parasite causes a reduction in this ratio, thus causing a reduction in nutrient absorption. Idris et al. (1997) stated that shortening of the villi in the duodenum and jejunum has a significant effect with regard to reduction of nutrient absorption and digestion surface area, which is directly reflected in significantly lower growth rates among infected animals.

Although E. maxima affects the jejunal area and compromises its defense through lower ability to absorb nutrients, this did not reflect negatively on the birds' weight gain under the conditions to which they were subjected in the present study. However, the mean weight gains of the control group were always greater than those of the infected group during the experimental period. Equivalent results were found by Zulpo et al. (2007), who did not obtain any significant differences in weight gain, but the means were always lower for the infected group.

The normal plasma values for glucose can be linked to the hepatic glycogenolysis carried out by the bird, in which the glucose is kept at its baseline levels by means of breakdown of hepatic glycogen through glucagon release by the pancreas (RUFF; WILKINS, 1980; FREITAS et al., 2008). According to Chapman et al. (1982), the bird's ability to maintain normal blood glucose levels in situations in which the reserves of hepatic 
glycogen are exhausted is due to gluconeogenesis or reduction of the bird's use of glucose.

Similar results were found by Chapman et al. (1982), when inoculating $1 \times 10^{5}$ sporulated oocysts of $E$. maxima, i.e. a higher dosage than the one used in the present study. They observed that the glucose concentrations remained nearly analogous between the infected and the control groups. However, divergent results were found by Ruff and Wilkins (1980) in studying glucose absorption in birds infected by E. maxima, with the observation that this parasite caused alterations to glucose absorption in the acute phase of the disease. However, on the $21^{\text {st }} \mathrm{dpi}$, alterations to the plasma concentrations of glucose were no longer observed.

The slight hypoproteinemia observed in the acute phase of the disease ( $11^{\text {th }} \mathrm{dpi}$ ) was probably due to loss of proteins through the intestine wall, which could also have contributed towards higher weight loss among the infected birds. Similar results were obtained by Chapman et al. (1982) when inoculating $1 \times 10^{5}$ sporulated oocysts of E. maxima. They observed that the birds presented slight hypoproteinemia in the acute phase of the disease ( $4^{\text {th }} \mathrm{dpi}$ ), without returning to normal values until the $10^{\text {th }} \mathrm{dpi}$. Since the liver is responsible for albumin production, the normal concentrations of this protein found in the present study were as expected, since the parasite does not cause damage to this organ.

The lower serum calcium concentration and its effects on the birds' performance, such that they presented lower weight at slaughter, were repercussions of the reduction of serum phosphorus concentration, as shown by Parmer et al. (1987) and Runho et al. (2001). They found that birds with lower serum phosphorus concentrations presented hypocalcemia, hypophosphatemia and lower weight and length.

Coccidiosis causes plasma reduction of lipids due to alterations caused in the mucosa of the intestinal epithelium. The significant reductions in the absorption of VLDL-c and triacylglycerol were followed by reductions of total cholesterol, HDL-c, and LDL-c, which presented means lower than in the infected group, even though these reductions were not significant. This shows that the dosage of E. maxima used caused reductions in lipid absorption. Freitas et al. (2008) studied the alterations in the metabolism of broiler chicken experimentally infected with $E$. acervulina (an enteric parasite), and observed that all classes of lipids in the serum, and lipoproteins, were reduced in infected birds.

The reduction in absorption in the acute phase of the disease may be connected with various factors. First, infections by coccidia lead to reduction of the $\mathrm{pH}$ of the intestinal lumen and, therefore, can retard the action of hydrolases (RUFF; WILKINS, 1980). Second, infections by coccidia affect the mucosa of the jejunum both qualitatively and quantitatively, thus affecting lipid absorption. There are qualitative changes to the absorption surface, which is reduced due to desquamation and atrophy of the villi. Studies in other species of coccidia have indicated that the nutritional effects from parasitism depend on the area in which it occurs, the severity of the infection, the phase of the cycle and the nutrient that was studied (TURK; STEPHENS, 1969).

According to Gabriel et al. (2003), occurrences of nutritive disorders that lead to reduction in the birds' weight gain are expected in infections by E. maxima. Idris et al. (1997) inoculated $2.5 \times 10^{3}$ sporulated oocysts of E. maxima, i.e. half of the dosage used in the present experiment, and observed that the infected birds presented lower weight than the control group. They concluded that this parasite caused growth retardation in the birds in the initial period, which is a critical period for full development of the birds' organic functions. Similar results were also obtained by Gabriel et al. (2003) using dosages of $5 \times 10^{3}$ and $5 \times 10^{4}$ of sporulated oocysts of E. maxima, in which the birds that were subjected to the greater challenge presented lower weight gain than shown by the birds with the smaller challenge. Zulpo et al. (2007) also reported lower weight gain among birds infected by E. maxima, when using a dosage of $2 \times 10^{4}$.

\section{Conclusions}

Under the conditions established for the present experiment, it is possible to conclude that infection by E. maxima causes both qualitative and quantitative alterations to the structure of the intestinal villi, thereby interfering with the absorption of nutrients such as calcium, phosphorus, magnesium, protein and lipids, with consequent reductions in the birds' weights.

\section{References}

Cardozo SP, Yamamura MY. Identificaçáo de espécies de Eimeria sp e avaliação do escore de lesóes intestinais entre frangos vacinados e tratados com anticoccidiano, produzidos no sistema colonial/caipira. Semina: Ciênc Agrár 2006; 27(2): 261-270. http://dx.doi.org/10.5433/16790359.2006v27n2p261

Chapman HD, Fernandes DL, Davison TF. A comparison of the effects of infection with Eimeria maxima and dietary restriction on weigth gain, plasma metabolites and liver glycogen in the immature fowl, Gallus domesticus. Parasitology 1982; 84(2): 205-213. PMid:7070839. http:// dx.doi.org/10.1017/S0031182000044772

Costa CAF, Paiva DP. Cultivo in vivo, in vitro e diagnóstico especifico de Eimeria spp. de Gallus Gallus. Brasília: Embrapa Informação Tecnológica; 2009.

Freeman BM. Carbohydrate stores in chickens infected with Eimeria tenella. Parasitology 1970; 61(2): 245-251. PMid:5483914. http://dx.doi. org/10.1017/S0031182000041068

Freitas FLC, Almeida KS, Machado RZ, Machado CR. Lipid and glucose metabolism of broilers (Gallus gallus domesticus) experimentally infected with Eimeria acervulina Tyzzer, 1929 oocysts. Braz J Poult Sci 2008; 10(3): 157-162.

Gabriel I, Mallet S, Leconte M, Fort G, Naciri M. Effects of Whole Wheat Feeding on the Development of Coccidial Infection in Broiler Chickens. Poult Sci 2003; 82(11): 1668-1676. PMid:14653460. http:// dx.doi.org/10.1093/ps/82.11.1668

Idris AB, Bounous DI, Goodwin MA, Brown J, Krushinskie EA. Quantitative pathology of small intestinal coccidiosis caused by Eimeria maxima in young broilers. Avian Pathol 1997; 26(4): 731-747. PMid:18484266. http://dx.doi.org/10.1080/03079459708419249

Jang SI, Lillehoj HS, Lee SH, Lee KW, Park MS, Cha SR, et al. Eimeria maxima recombinant Gam82 gametocyte antigen vaccine protects against coccidiosis and augments humoral and cell-mediated immunity. Vaccine 2010; 28(17): 2980-2985. PMid:20178868. http://dx.doi. org/10.1016/j.vaccine.2010.02.011 
Jenkins M, Fetterer R, Miska K. Co-infection of chickens with Eimeria praecox and Eimeria maxima does not prevent development of immunity to Eimeria maxima. Vet Parasitol 2009; 161(3-4): 320-323. PMid:19217719. http://dx.doi.org/10.1016/j.vetpar.2009.01.012

Lillehoj HS, Okamura M. Host immunity and vaccine development to coccidia and salmonella infections in chickens. Poult Sci 2003; 40(3): 151-193. http://dx.doi.org/10.2141/jpsa.40.151

McDougald LR. Protozoal Infections. In: Saif YM. Diseases of poultry. Ames: Iowa State Press; 2007.

Montagne L, Pluske JR, Hampson DJ. A review of interactions between dietary fibre and the intestinal mucosa, and their consequences on digestive health in young non-ruminant animals. Anim Feed Sci Technol 2003; 108(1-4): 95-117. http://dx.doi.org/10.1016/S03778401(03)00163-9

National Research Council - NRC. Nutrient Requirements of Swine. Washington: National Academy Press; 1998.

Parmer TG, Carew LB, Alter FA, Scanes CG. Thyroid function, growth hormone, and organ growth in broiler deficient in phosphorus. Poult $S_{c i}$ 1987; 66(12): 1995-2004. PMid:3452219. http://dx.doi.org/10.3382/ ps.0661995

Pelicano ERL, Souza PA, Souza HBA, Oba A, Norkus EA, Kodawara LM, et al. Morfometria e Ultra-Estrutura da Mucosa Intestinal de Frangos de Corte alimentados com Dietas contendo diferentes Probióticos. Rev Port Ciênc Vet 2003; 98(547): 125-134.

Ruff MD, Wilkins GC. Total intestinal absorption of glucose and 1-methionine in broilers infected with Eimeria acervulina, E. mivati, E. maxima or E. brunetti. Parasitology 1980; 80(3): 555-569. PMid:7393622. http://dx.doi.org/10.1017/S0031182000001013

Runho RC, Gomes PC, Rostagno HS, Albino LFT, Lopes OS, Pozza PC. Exigência de fósforo disponível para frangos de corte machos e fêmeas de 1 a 21 dias de idade. Rev Bras Zootec 2001; 30(1): 187-196. http:// dx.doi.org/10.1590/S1516-35982001000100027

Sharman PA, Smith NC, Wallach MG, Katrib M. Chasing the golden egg: vaccination against poultry coccidiosis. Parasite Immunol 2010, 32(8): 590-598. PMid:20626814.

Turk DE, Stephens JF. Coccidial infections of the ileum, colon, and ceca of the chick and nutrient absorption. Poult Sci 1969; 48(2): 586-589. http://dx.doi.org/10.3382/ps.0480586

Zulpo DL, Peretti J, Ono LM, Longhi E, Oliveira MR, Guimarães IG, et al. Pathogenicity and histopathological observations of commercia broiler chicks experimentally infected with isolates of Eimeria tenella, $E$. acervulina and E. maxima. Semina: Ciênc Agrár 2007; 28(1): 97-104. http://dx.doi.org/10.5433/1679-0359.2007v28n1p97 